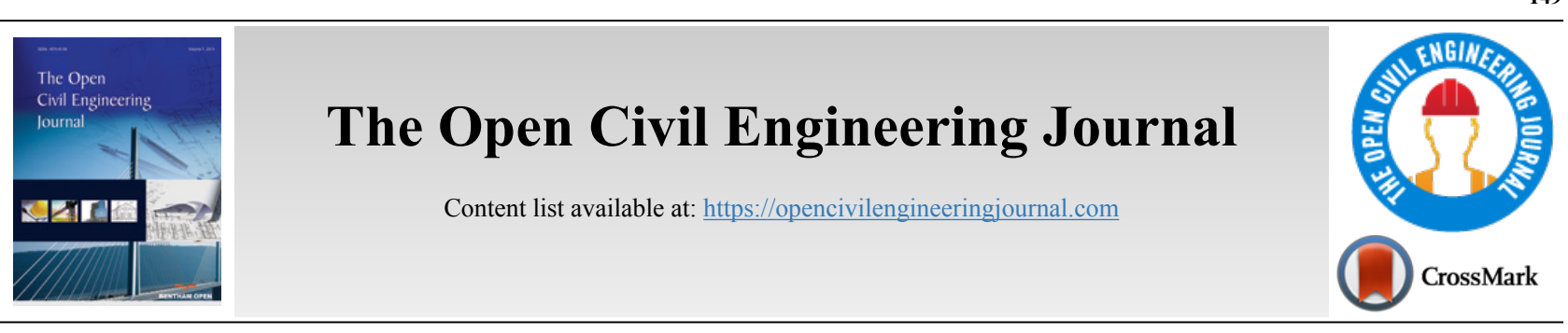

RESEARCH ARTICLE

\title{
Influence of Local Site Effects on the Typological Fragility Curves for Class- Oriented Masonry Buildings in Aggregate Condition
}

\author{
Antonio Formisano ${ }^{1,}$, Nicola Chieffo ${ }^{2}$, Francesco Clementi $^{3}$ and Marius Mosoarca ${ }^{2}$ \\ ${ }^{\prime}$ Department of Structures for Engineering and Architecture, School of Polytechnic and Basic Sciences, University of Naples “Federico II” 80125 \\ Naples, Italy \\ ${ }^{2}$ Faculty of Architecture and Urbanism, Politehnica University of Timişoara, Traian Lalescu Street, 300223 Timişoara, Romania \\ ${ }^{3}$ Department of Civil and Building Engineering and Architecture, Polytechnic University of Marche Via Brecce Bianche, 60131 Ancona, Italy
}

\begin{abstract}
:
Background:

The Municipality of Baranello, located in the province of Campobasso, is considered as a reference case study for implementing a systematic procedure for the assessment of local site effects. The territory is characterised by a heterogeneous soil, made of a basal interval formed in large part by outcrops found along with the middle-basal bands of the local slopes, which is particularly sensitive to geo-hazard effects.

Aims:

The present work aims to investigate the influence of local site effects on the seismic vulnerability of an oriented- class of masonry building compounds. The historical buildings surveyed are mainly made up of rough stone masonry, particularly vulnerable to seismic phenomena. The buildings are appropriately grouped in typological classes based on the CARTIS form and then subdivided into different categories according to the EMS-98 scale based on their geometrical and structural characteristics.

Methods:

The performed vulnerability analysis is based on a vulnerability-index method conceived for buildings grouped in aggregate condition. Moreover, the expected damage scenario is properly evaluated based on a specific attenuation law to take into consideration the effect produced by a reference scenario event. Furthermore, the local site conditions have been evaluated based on a $1 \mathrm{D}$ half space approach in order to predict the possible increment of the expected damage due to the soil stratigraphy.

Results:

The local site conditions provide a global increment of the expected vulnerability of $33 \%$ with respect to the case in which the geo-hazard effects are neglected. In this activity framework, typological fragility curves are derived for comparing the exceeding probability thresholds for the examined building classes.

\section{Conclusion:}

The proposed research represents an important starting point for large-scale vulnerability assessment since it provides a simplified and comprehensive method for predicting seismic damage scenarios of historic center considering local site effects.
\end{abstract}

Keywords: Vulnerability assessment, Masonry building compounds, Large-scale analysis, Damage scenarios, Site effects, Attenuation law, Vulnerability curves, Fragility curves.

\begin{tabular}{|l|l|l|l|}
\hline Article History & Received: December 31, 2020 & Revised: January 7, 2021 Accepted: January 14, 2021 & .
\end{tabular}

\section{INTRODUCTION}

The tragic earthquakes that occurred in Italy in recent years were a consistent testimony of low seismic performance levels of historical centres of many municipalities due to a series of

\footnotetext{
* Address correspondence to this author at Department of Structures for Engineering and Architecture, School of Polytechnic and Basic Sciences, University of Naples "Federico II" 80125 Naples, Italy;

E-mail: antoform@unina.it
}

deficient factors, such as the age of buildings, the poor quality of materials and the scarce maintenance state of constructions, which led towards significant seismic damages.

Generally, in an overall overview, the Vulnerability (V), combined through a multi-factorial procedure with other two parameters, such as Exposure (E) and Hazard $(\mathrm{H})$, leads to the definition of the seismic risk, which can have a direct or indirect influence on a specific site. Reducing the expected 
level of seismic risk means assessing the seismic capacity of buildings sample towards earthquakes (Vulnerability), the amount of human and material resources that could be lost in case of seismic events (Exposure) and the intensity and recurrence of earthquakes (Hazard).

The seismic vulnerability of a given built area denotes the expected amount of damage caused by an earthquake with a specific Intensity Measurement (IM) [1]. In this perspective, the seismic vulnerability assessment of an urban centre is devoted to estimate the propensity of the built-up area to undergo seismic phenomenon without failures, which are responsible for huge economic losses and casualties.

In this framework, focusing on the urban scale, rapid urbanization has dramatically increased the vulnerabilities of the exposed material assets of urban dwellers in densely populated areas. The high population growth and the presence of a conspicuous number of buildings designed without antiseismic regulations significantly have expanded the problem of seismic safety condition in urbanized areas $[2,3]$.

At urban-scale, the identification of the most vulnerable class-oriented buildings is not a simple task due to their structural heterogeneity and complexity. In general, the susceptibility of buildings to be damaged by a scenario event depends on many aspects, such as (i) The construction type, (ii) The quality of materials used, (iii) The construction methods and (iv) The preservation state. Many studies [4 - 6] have highlighted how the lack of these peculiarities makes structures ineffective against seismic actions. In particular, it is worth noting how especially masonry buildings located in historic centres are often characterized by a static inadequacy, mainly due to unsuitable construction techniques, which do not guarantee an adequate safety level. To this purpose, an inventory of building typologies is an essential procedure for the acquisition of preliminaries data aiming at performing large-scale seismic vulnerability [7,8].

The available strategies usually take into consideration survey forms $[9,10]$ to collect several seismic parameters of historical buildings, i.e. the seismic-resistant system type to lateral loads, the structural regularity, the maintenance conditions and the presence of existing damages. The application of these survey forms allows to fully understand various structural typologies located within heterogeneous urban centres [4]. Thus, in this perspective, the impact of an earthquake can be assessed in terms of expected losses facilitating risk management purposes. In fact, the formulation of an adequate earthquake loss model in a given region is not only essential for economic purpose due to the impact of future earthquakes, but it is also important for risk mitigation measures. A specific seismic loss model allows to predict the expected damage of the built environment due to a specific event and could be particularly important for a systematic action aimed at emergencies planning in order to safeguard people and historical heritage of a given site [11 - 13].

Nowadays, in the framework of seismic risk assessment, another important aspect regards the evaluation of the geological effects in order to have a better and correct forecast of the expected structural damage [14].
In this circumstance, the soil layers can amplify or reduce the effect of the seismic waves at ground surface. Site effects are, thus, dangerous when the amplification of seismic waves in surface geological layers occurs since it produces an increase of expected physical damage of some building classes even in case of low-intensity/magnitude earthquakes. In fact, surface motion can be strongly amplified if geological conditions are unfavourable [15].

Generally, all these phenomena are called site or local amplification effects. The characterization of site effects can be carried out considering the ground model as a $1 \mathrm{D}$ or 2D halfspace. In a $1 \mathrm{D}$ analysis only the depth of the half-space is taken into consideration, neglecting the lateral confinement effect, while the more accurate 2D analysis considers the significant volume of soil in the longitudinal and vertical directions. The study of site effects can be conducted using the above two distinct procedures in either the time domain or the frequency domain. In the first case, the local amplification factor is estimated by means of the time sequence (time history) at the bedrock with respect to the amplification at the ground surface. In the second case, the amplification coefficient is determined considering the Fourier amplitude spectra based on a proper response spectrum [16].

A reliable and easy method for large scale analysis developed in $[14,16]$ allows to estimate the macro seismic intensity increment derived from a specific soil category, so as to properly define, taking into account the local amplification factors, the global vulnerability of building stocks according to the EMS-98 scale. As proposed in [14], the site conditions have been evaluated through the definition of the acceleration design response spectrum of a given geographical area, accounting for the soil type based on the shear waves, $\mathrm{V}_{\mathrm{s} 30}$, and neglecting the real soil stratigraphy [17].

Thus, starting from the study [14], the present research aims to propose a systematic and simplified procedure for assessing geological site effects in an organic and comprehensive way. The proposed methodology provides an integrated assessment of seismic vulnerability considering the influence of site effects on the structural response of a sample of buildings. The main aspect of this methodology is its straightforward execution, since it is applicable to any seismic area considering as input parameters the site stratigraphy and the reference seismic event.

Based on these considerations, the municipality of Baranello, in the province of Campobasso, has been selected as a reference case study to evaluate the possible damages of the built-up area under seismic events considering local site effects through a $1 \mathrm{D}$ half-space ground model in the time domain. The main goal of this work is to investigate the influence of soil condition on the seismic behaviour of typical masonry aggregates with the final target to plot the damage scenarios in terms of typological fragility curves derived from an empiricalbased approach that correlates the macro seismic intensity of the site to the expected seismic acceleration. 


\section{MATERIALS AND METHODS}

\subsection{Survey and Analysis Methods}

\subsubsection{Historical Background of the Municipality of Baranello}

Baranello (Fig. 1) is a small town located in the province of Campobasso in the Molise Region of Italy. The municipality has 2759 inhabitants and rises at $610 \mathrm{~m}$ above sea level with an extended area of $25 \mathrm{~km}^{2}$. The town, which has medieval origins, is bordered by the towns of Busso, Colle d'Anchise, Spinete and Vinchiaturo.

There there are limited historical informations about the evolution of the centre over the time. The village was mentioned for the first time in the $14^{\text {th }}$ century as a possession of Capece Galeota dating back to Norman ages. Only in 1591 the feud was sold by the Carafa family to the Marquis and then to Angelo Barone. Until the $19^{\text {th }}$ Century, Baranello was part of the Aragonese domain and, subsequently, of the Ruffo family. Within the village, an example of Norman architecture was found in the Ruffo castle, owned by the homonymous family until the $19^{\text {th }}$ century. The castle was built at the highest point of the ancient village, performing its function of defence and control of the entire territory.

Nowadays, the territory presents the characteristics of a mountain centre: there is the predominance of narrow and steep streets that become wider and easier towards the area of a new settlement. The urban centre is mainly characterized by houses which maintain their original appearance and are located around the church and along the main streets, while the modern buildings are placed in other districts belonging to the municipal territory [18].

\subsubsection{Typological and Structural Characterization of the Urban Centre}

The structural and typological characterization of urban centres is an important step in order to have specific census data of the main building tipologies exposed at the seismic risk.

In the examined specific context, the CARTIS form has been used in order to detect the prevalent ordinary building typologies in the historical centre of Baranello. The CARTIS form has been conceived by the PLINIVS research centre of the University of Naples "Federico II" in collaboration with the Italian Civil Protection Department (DPC) during the ReLUIS 2014-2016 project "Development of a systematic methodology for the assessment of exposure on a territorial scale based on the typological/structural characteristics of buildings" [12, 19].

The form is mainly divided into four sections: Section 0 , for the identification of the municipality and the sectors identified therein; Section 1, for the recognition of each of the relevant typologies characterizing the generic sub-sector of the assigned municipality; Section 2, for the detection of general characteristics of each typology of constructions; Section 3, for the characterization of structural elements of all individuated construction typologies. Focusing on the case study, the historical centre of Baranello is composed of a unique compartment, named $\mathrm{C} 01$ and made of 300 buildings (Fig. 2).
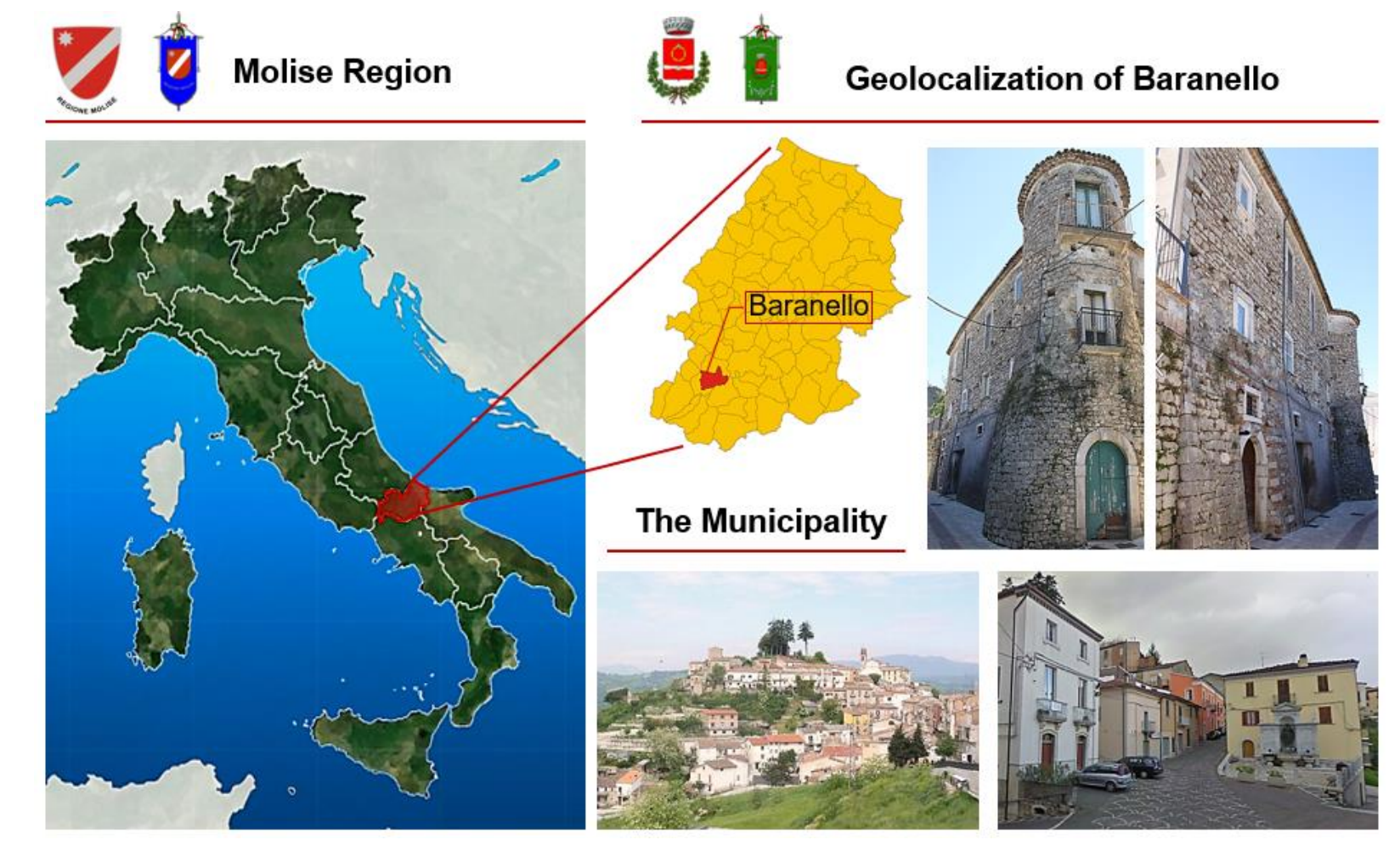

\section{Geolocalization of Baranello}

Fig. (1). Geo-localization of the municipality of Baranello. 


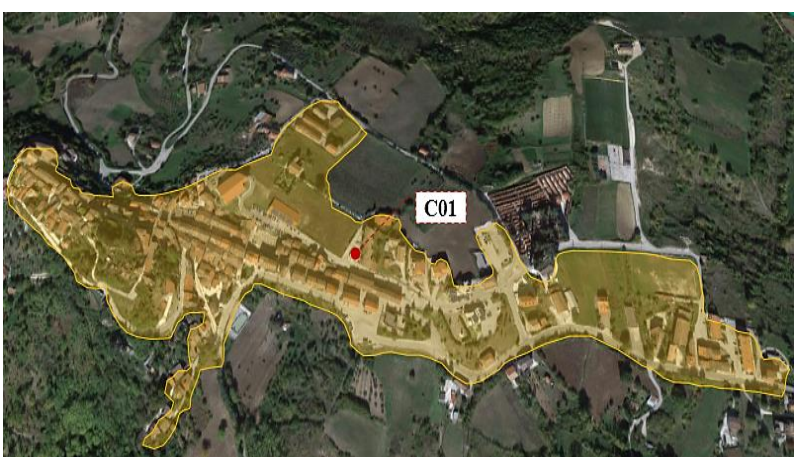

Fig. (2). C01 compartment of the historical centre of Baranello.

In the examined sector, most of the buildings have been built using rough-hewn stones assembled according to the technique of sack or mixed walls, which in some cases have greatly affected the characteristics and quality of constructions, offering substantial deficiencies in terms of global response towards seismic actions. In particular, the houses characterising the historical centre are composed of masonry walls with an average thickness of $0.65 \mathrm{~m}$ and an average inter-storey height of $3.50 \mathrm{~m}$. Apart masonry vaults, the horizontal structures, as well as roofs, are generally made of either timber or steel beams (Fig. 3).

The data collected through the CARTIS form has been elaborated statistically to provide indications on constructive age, number of storeys, average surface area and wall type of the sample of buildings surveyed within the municipality examined. The results obtained are plotted in the cumulative distributions reported in Fig. (4).

From the data collected on the 300 inspected buildings, the prevailing typological class is the MUR2 (rough-hewn stone) one, which has been detected in $75 \%$ of the cases $(225$ buildings). Moreover, about $10 \%$ of the sample are abandoned (acronym A. B. in Fig. (4)).

\subsubsection{Derivation of the Damage Probability Matrices (DPM)}

After the earthquake occurred in Friuli in 1976, the investigation of post-earthquake damage to ordinary buildings has become a crucial priority for emergency management of the Italian historical cities. To this purpose, the PostEarthquake Damage and Safety Assessment (AeDES) form was introduced in 1997 as an efficient operational tool, recognized by the Italian Civil Protection Department for the detection and management of post-earthquake emergencies (Fig. 5) [20].
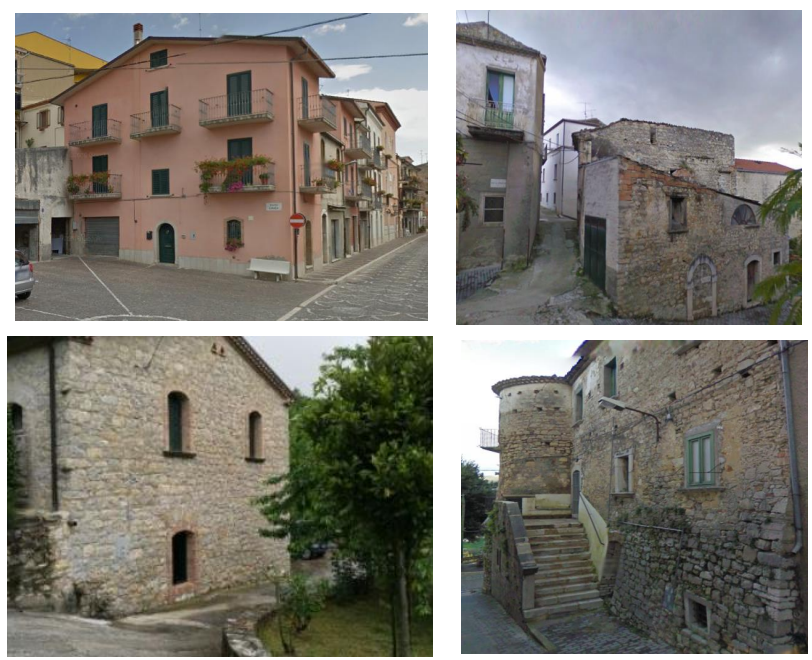

Fig. (3). Street views of the characteristic building typologies within the historical centre of Baranello.
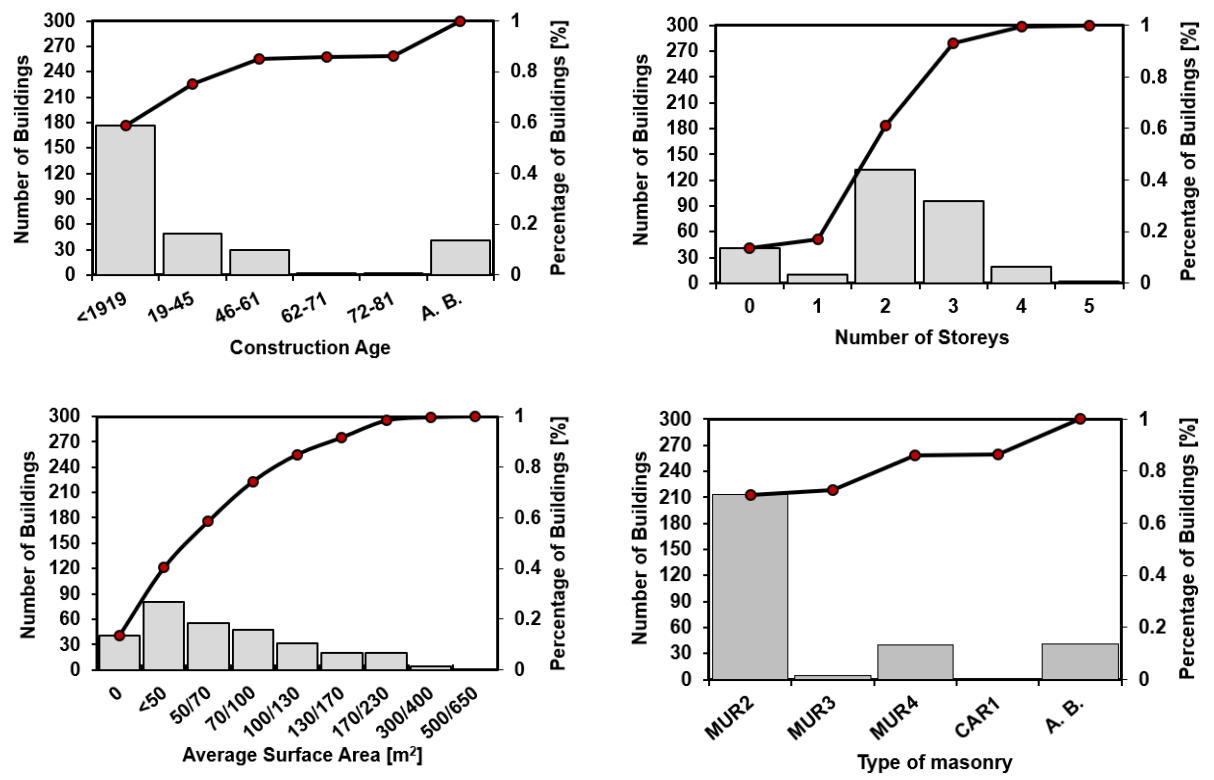

Fig. (4). Preliminary construction characteristics of the buildings surveyed in the municipality of Baranello. 

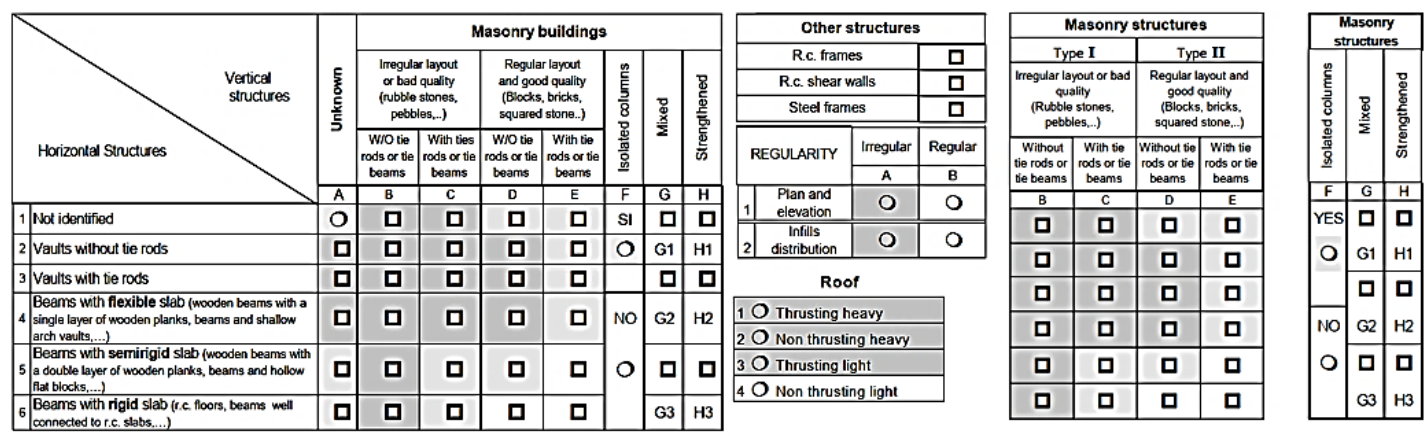

\begin{tabular}{|c|c|c|c|c|c|c|c|c|c|c|c|c|c|c|c|c|}
\hline \multirow{4}{*}{$\begin{array}{l}\text { Damage level } \\
\text {-extension }\end{array}$} & \multicolumn{10}{|c|}{ DAMAGE (1) } & \multicolumn{6}{|c|}{ EXISTING SHORT TERM COUNTERMEASURES } \\
\hline & \multicolumn{3}{|c|}{$\begin{array}{c}\text { D4.05 } \\
\text { very Heavy }\end{array}$} & \multicolumn{3}{|c|}{$\begin{array}{c}02.03 \\
\text { Medium-Severe } \\
\end{array}$} & \multicolumn{3}{|c|}{$\begin{array}{l}\text { D1 } \\
\text { Light }\end{array}$} & \multirow[b]{2}{*}{$\overline{\overline{3}}$} & \multirow[b]{2}{*}{$\frac{8}{2}$} & \multirow[b]{2}{*}{ 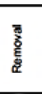 } & \multirow[b]{2}{*}{ 菟 } & \multirow[b]{2}{*}{ 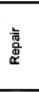 } & \multirow[b]{2}{*}{ 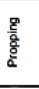 } & \multirow[b]{2}{*}{ 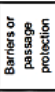 } \\
\hline & $\overbrace{\Lambda}^{2}$ & & $\frac{2}{2}$ & 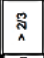 & 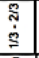 & $\frac{9}{2}$ & $\stackrel{\text { กิ }}{\wedge}$ & 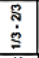 & $\frac{9}{2}$ & & & & & & & \\
\hline & & $\mathrm{B}$ & $\mathrm{c}$ & $\mathrm{D}$ & $E$ & $F$ & $G$ & $\mathrm{H}$ & & 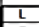 & A & $\bar{B}$ & & 0 & & \\
\hline \begin{tabular}{l|l|}
1 Vertical structures \\
\end{tabular} & 口 & 口 & 口 & 口 & 口 & 口 & 口 & 口 & 口 & 0 & 0 & 口 & 口 & 口 & 口 & 口 \\
\hline \begin{tabular}{l|l|l|}
2 & Floors \\
\end{tabular} & 므 & 口 & 므 & 므 & 口 & 口 & 口 & 므 & 므 & O & $\mathrm{O}$ & 口 & 口 & 口 & 口 & 口 \\
\hline 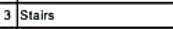 & 口 & 可 & 可 & 口 & 可 & 可 & 口 & 可 & 可 & 0 & O & 口 & 口 & 口 & $\bar{\square}$ & प् \\
\hline \begin{tabular}{|l|l|}
4 & Roof \\
\end{tabular} & 口 & 可 & 可 & 口 & 口 & 口 & 口 & 口 & 口 & O & O & 口 & 口 & 口 & 口 & 口 \\
\hline 5 Infills and partitions & $\bar{\square}$ & प्र & 므 & 며 & 可 & 문 & 므 & 면 & 므 & 0 & O & 口 & & 口 & 口 & 口 \\
\hline Pe-existing damage & ㅁ & 可 & 口 & 口 & 口 & 口 & 口 & 口 & 口 & 0 & & & & & & \\
\hline
\end{tabular}

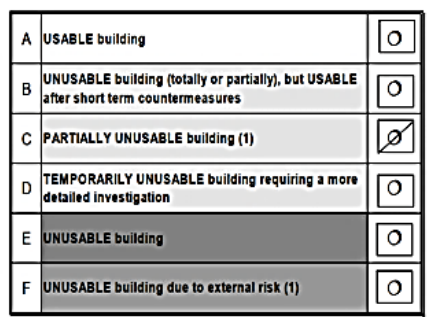

Fig. (5). Main section of the AeDES form.
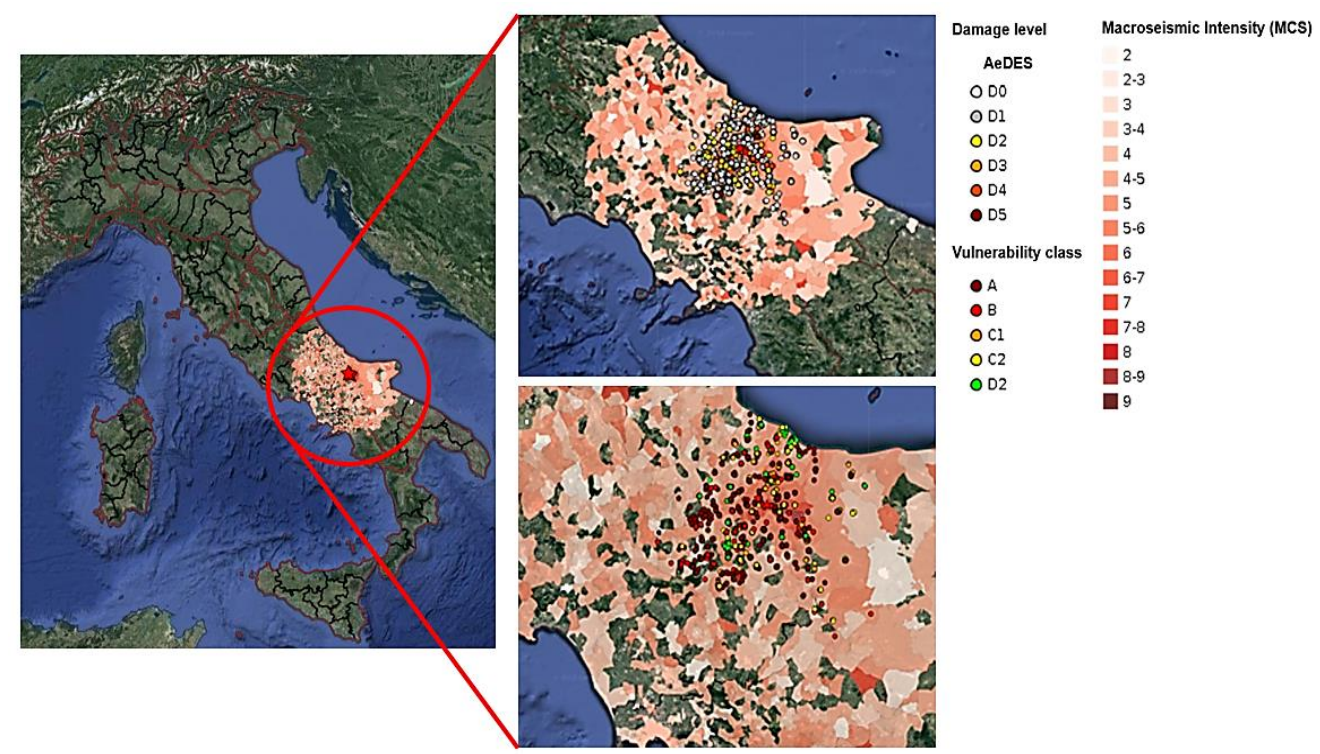

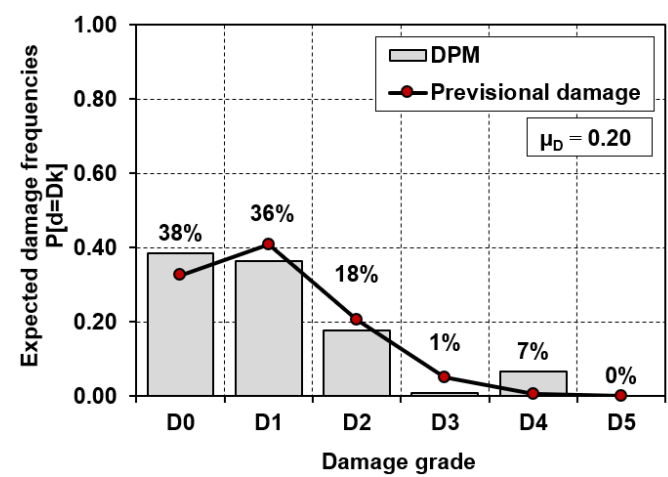

(b)

(a)

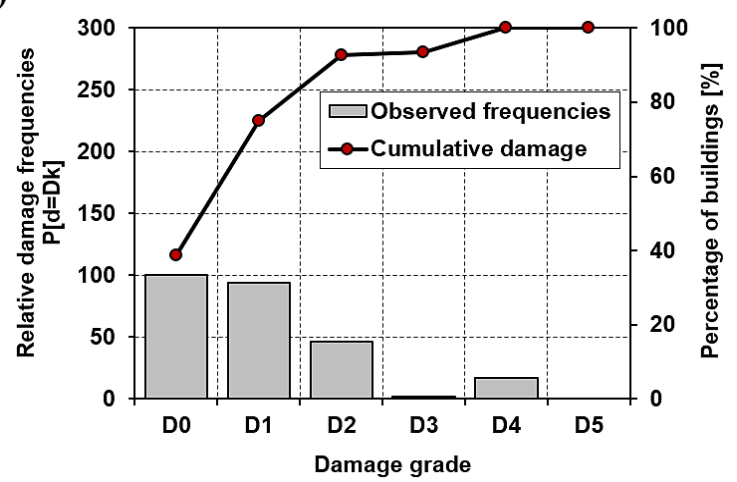

(c)

Fig. (6). Damage assessment: (a) Da.D.O database, (b) damage probability matrices and (c) cumulative damage distribution. 
Subsequently, in 2014, the Italian Civil Protection Department promoted a new scientific project with the aim of creating a new database at national level to simulate seismic risk scenarios. The project, in collaboration with the Eucentre Foundation (European Centre for training and research of Earthquake Engineering), led to the development of the WebGIS platform called Da.D.O (Observed Damage Database) [21]. This tool represents an important support for the scientific community since it collects and catalogues all the data, surveyed through the AeDES form, about both structural damages and main characteristics of inspected buildings detected after last past earthquakes (Friuli 1976, Irpinia 1980, Abruzzo 1984, Umbria and Marche 1997, Pollino 1998, Molise and Puglia 2002, Emilia-Romagna 2003, L'Aquila 2009 and Emilia-Romagna 2012). Thus, for the quantification of the observed damage, using the Da.D.O database and exploiting the information collected in the linked AeDES form, the Damage Probability Matrices (DPM) have been statistically processed using the binomial distribution function according to the following equation $[12,22]$ :

$$
\mathrm{p}_{\mathrm{k}}=\frac{5 !}{\mathrm{k} !(5-\mathrm{k}) !} \times\left(\frac{\mu_{\mathrm{D}}}{5}\right)^{\mathrm{k}} \times\left(1-\frac{\mu_{\mathrm{D}}}{5}\right)^{5-\mathrm{k}}
$$

Where $\mathrm{k}$ denotes the damage threshold variable from 0 to 5 according to the EMS-98 scale and $\mu_{\mathrm{D}}$ represents the weighted average of damages. In this context, the event occurred in Molise in 2002 (with epicentre in Bonefro) has been considered in order to collect the main information regarding typological classes, damage level occurred and macroseismic intensity of the study area. In Fig. (6) a representation of the DPM has been done.

Afterwards, based on the examined typological classification of the surveyed buildings, a typological correlation has been conducted among CARTIS, Da.D.O and EMS-98 in order to differentiate the prevalent typological vulnerability classes [12] based on the vertical bearing structure. The attribution of a vulnerability class takes place by means of acronyms identifying the materials characterizing the vertical structure. In this case, the transition from one vulnerability class to another, which provides the reduction of the vulnerability level derived from the CARTIS form (from irregular masonry stone buildings, MUR1, to reinforced concrete framed structures, $\mathrm{RC} 1$ ), has been based on the macroseismic method EMS-98, which incorporates all the typological classes derived from the AeDES form into four typological classes, from A (the worst) to $\mathrm{D}$ (the best). Thus, the typological vulnerability classes of the investigated urban area are shown in Fig. (7).

\section{RESULTS}

\subsection{Vulnerability-Based Approach}

A seismic vulnerability assessment at urban scale has been implemented in order to evaluate the propensity at the damage of buildings exposed at earthquakes. In this perspective, a vulnerability index-based method has been adopted. The peculiarity of this method, proposed in [23], is the possibility of investigating the seismic vulnerability of building compounds through the easy vulnerability form depicted in Table 1.

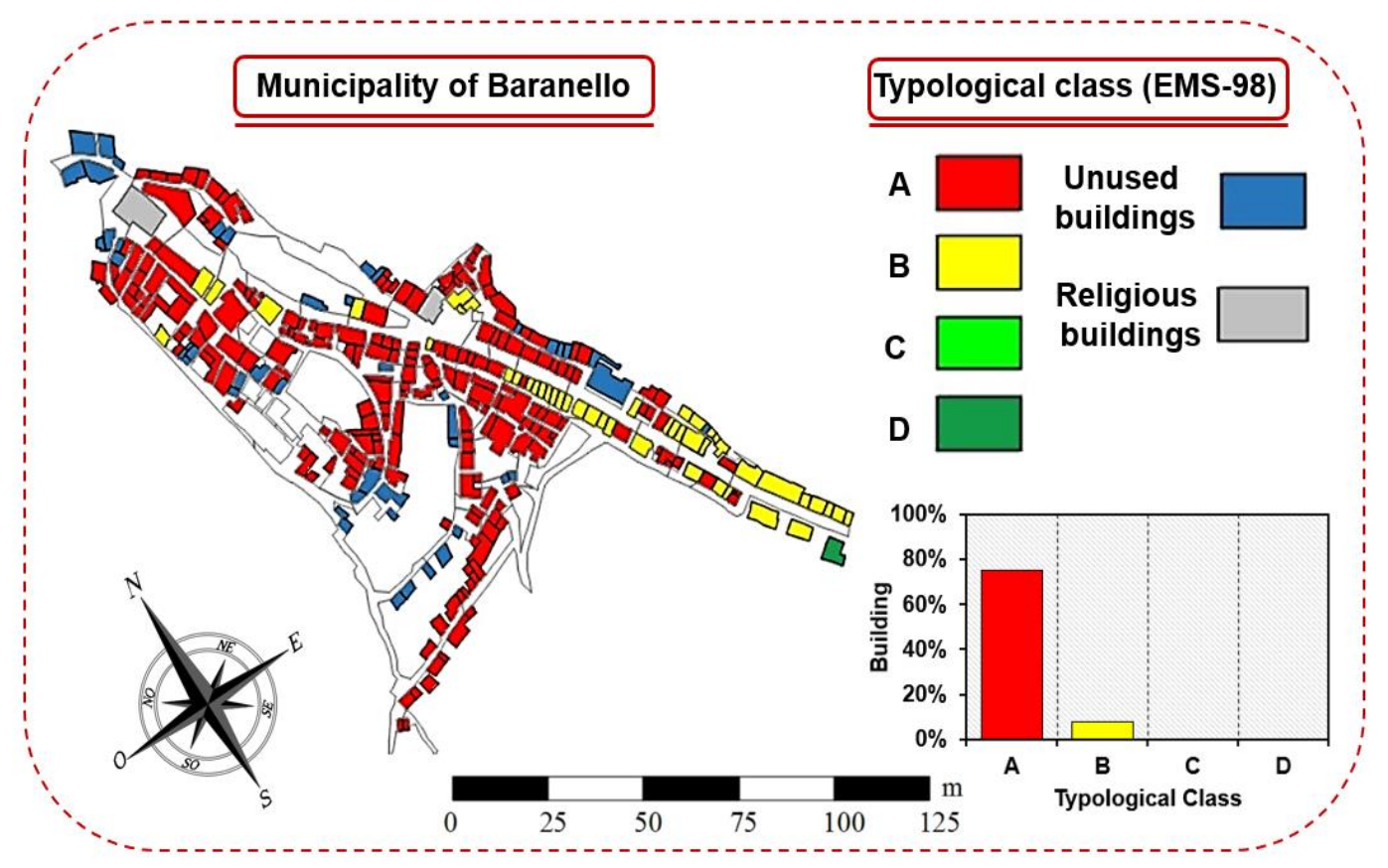

Fig. (7). Typological vulnerability classes of the municipality of Baranello derived from the EMS-98 scale. 
Table 1. Vulnerability form conceived for historical masonry building compounds.

\begin{tabular}{|c|c|c|c|c|c|}
\hline \multirow{2}{*}{ Parameters } & \multicolumn{3}{|c|}{ Class Score, $\boldsymbol{S}_{\boldsymbol{i}}$} & \multirow{2}{*}{ Weight, } \\
\cline { 2 - 4 } & $\mathrm{A}$ & $\mathrm{B}$ & $\mathrm{C}$ & $\mathrm{D}$ & $\boldsymbol{W}_{\boldsymbol{i}}$ \\
\hline 1. Organization of vertical structures & 0 & 5 & 20 & 45 & 1.00 \\
\hline 2. Nature of vertical structures & 0 & 5 & 25 & 45 & 0.25 \\
\hline 3. Location of the building and type of foundation & 0 & 5 & 25 & 45 & 0.75 \\
\hline 4. Distribution of plan resisting elements & 0 & 5 & 25 & 45 & 1.50 \\
\hline 5. In-plane regularity & 0 & 5 & 25 & 45 & 0.50 \\
\hline 6. Vertical regularity & 0 & 5 & 25 & 45 & 1.00 \\
\hline 7. Type of floor & 0 & 5 & 15 & 45 & 1.00 \\
\hline 8. Roofing & 0 & 15 & 25 & 45 & 0.75 \\
\hline 9. Details & 0 & 0 & 25 & 45 & 0.25 \\
\hline 10. Physical conditions & 0 & 5 & 25 & 45 & 1.00 \\
\hline 11. Presence of adjacent building with different height & -20 & 0 & 15 & 45 & 1.00 \\
\hline 12. Position of the building in the aggregate & -45 & -25 & -15 & 0 & 1.50 \\
\hline 13. Number of staggered floors & 0 & 15 & 25 & 45 & 0.50 \\
\hline 14. Structural or typological heterogeneity among adjacent S.U. & -15 & -10 & 0 & 45 & 1.20 \\
\hline 15. Percentage difference of opening areas among adjacent facades & -20 & 0 & 25 & 45 & 1.00 \\
\hline
\end{tabular}

This form, based on the original method proposed by Benedetti and Petrini some decades ago [24], has been appropriately extended to masonry building aggregates in 2015 [23] using five new additional parameters, which take into account the effects of mutual interaction among Structural Units (S.Us) under earthquakes.

Methodologically, the vulnerability index, $I_{v}$, is evaluated for each S.U. as the weighted sum of the class selected for each of the 15 parameters listed in Table $\mathbf{1}$ multiplied by the respective weight. The estimated parameters are grouped in 4 vulnerability classes (from $\mathrm{A}$, the best, to $\mathrm{D}$, the worst), characterised by a specific score (also with a negative sign in case of vulnerability reduction). To each parameter is assigned a given weight, $\mathrm{W}_{\mathrm{i}}$, which is variable from a minimum of 0.25 , for the less important parameters, up to a maximum of 1.50 , for the most important factors of the form [2, 23].

Thus, the vulnerability index, $I_{v}$, is calculated according to the following equation:

$$
\mathrm{I}_{\mathrm{V}}=\sum_{\mathrm{i}=1}^{15} \mathrm{~S}_{\mathrm{i}} \times \mathrm{W}_{\mathrm{i}}
$$

where, $\mathrm{S}_{\mathrm{i}}$, is the score associated to the $i$-th parameter, and $\mathrm{W}_{\mathrm{i}}$ is the $i$-th parameter weight.

Subsequently, the vulnerability index value $I_{V}$ is normalized in the range $(0-1)$, taking the notation of $\mathrm{V}_{\mathrm{I}}$, by means of the following equation:

$$
\mathrm{V}_{\mathrm{I}}=\left\lfloor\frac{\mathrm{I}_{\mathrm{V}}-\left(\sum_{\mathrm{i}=1}^{15} \mathrm{~S}_{\min } \times \mathrm{W}_{\mathrm{i}}\right)}{\left|\sum_{\mathrm{i}=1}^{15}\left[\left(\mathrm{~S}_{\max } \times \mathrm{W}_{\mathrm{i}}\right)-\left(\mathrm{S}_{\min } \times \mathrm{W}_{\mathrm{i}}\right)\right]\right|}\right\rfloor
$$

where: $I_{V}$ is the vulnerability index deriving from Eq. (2);
$\left(\mathrm{S}_{\min } \times \mathrm{W}_{\mathrm{i}}\right)$, equal to -125.50 , represents the sum of scores associated to the vulnerability class $\mathrm{A}$ of each parameter multiplied by respective weights; $\left(\mathrm{S}_{\max } \times \mathrm{W}_{\mathrm{i}}\right)$, equal to 495.00, represents the sum of scores associated to the vulnerability class $\mathrm{D}$ of each parameter multiplied by the respective weights.

Thus, the distribution of the vulnerability indices of typological classes examined has been represented in Fig. (8).

The results have shown that the distribution of the vulnerability is homogeneous, with an expected medium-high vulnerability level enclosed in the range (0.4-0.6) for typological class $\mathrm{A},\left(\mathrm{V}_{\mathrm{I} \text {, mean }}=0.55\right)$. Instead, for the analysed typological class $\mathrm{B}$, the expected frequency is in the range $(0.2-0.4)$, which corresponds to a moderate vulnerability level $\left(\mathrm{V}_{\mathrm{I}, \text { mean }}=0.36\right)$.

Subsequently, the typological vulnerability curves $[2,11$, 1] have been evaluated in order to estimate the propensity of damage of the building stock varying the level of macroseismic intensity, as reported in Fig. (9).

Mathematically, these curves have been derived according to the following relationship:

$$
\mu_{\mathrm{D}}=2.5 \times\left[1+\tanh \left(\frac{\mathrm{I}_{\mathrm{EMS}-98}+6.25 \times \mathrm{V}_{\mathrm{I}}-13.1}{\mathrm{Q}}\right)\right]
$$

where $\mathrm{V}_{\mathrm{I}}$ is the normalized vulnerability index, $\mathrm{I}_{\mathrm{EMS}-98}$ is the seismic hazard expressed in terms of macroseismic intensity and $\mathrm{Q}$ is the ductility factor, which describes the ductility of a certain typological class and assumes, in this specific study, the value of 2.3, as suggested in [14].

In Fig. (9) the vulnerability curves have been associated with other four curves, which represent the upper and lower bounds $\left(\mathrm{V}_{\mathrm{m}}-\sigma ; \mathrm{V}_{\mathrm{m}}+\sigma ; \mathrm{V}_{\mathrm{m}}+2 \sigma ; \mathrm{V}_{\mathrm{m}}-2 \sigma\right)$ of the statistical interval of the expected damage $[2,12]$. 


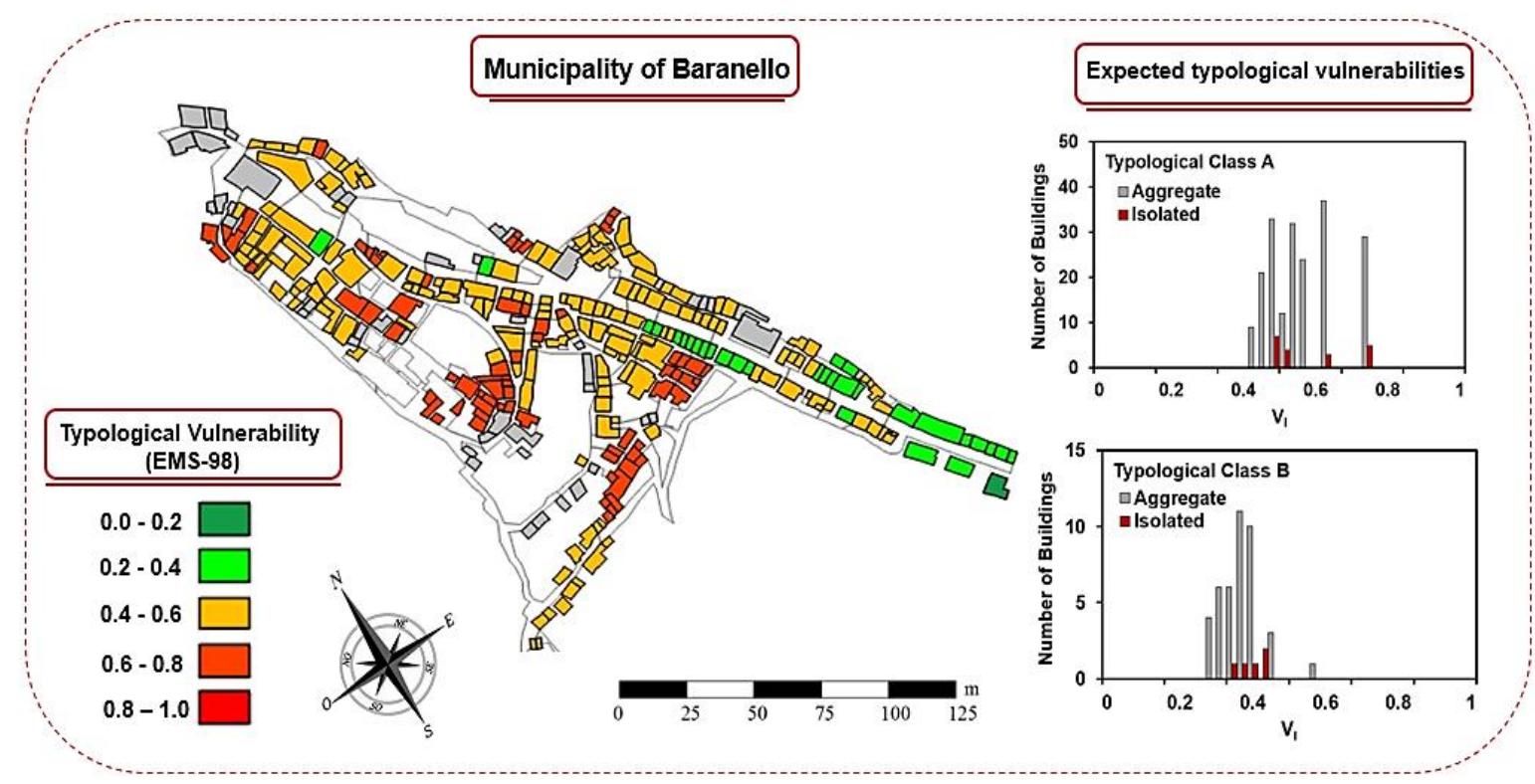

Fig. (8). Vulnerability Distribution of Building Typological Classes in the Examined Municipality.

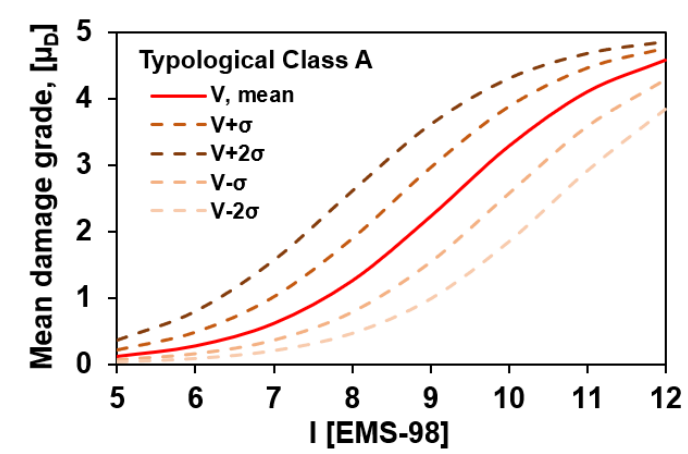

(a)

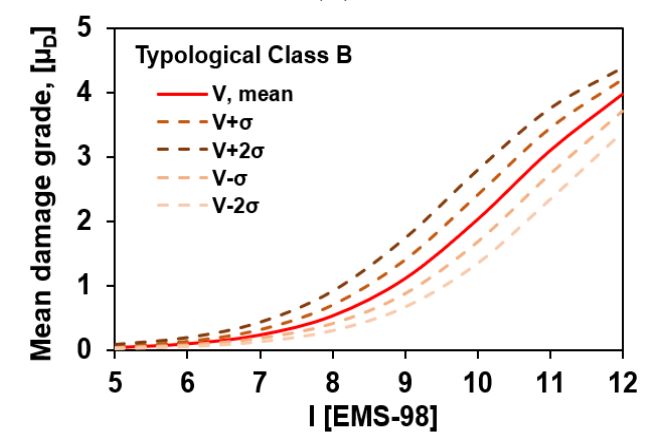

(c)

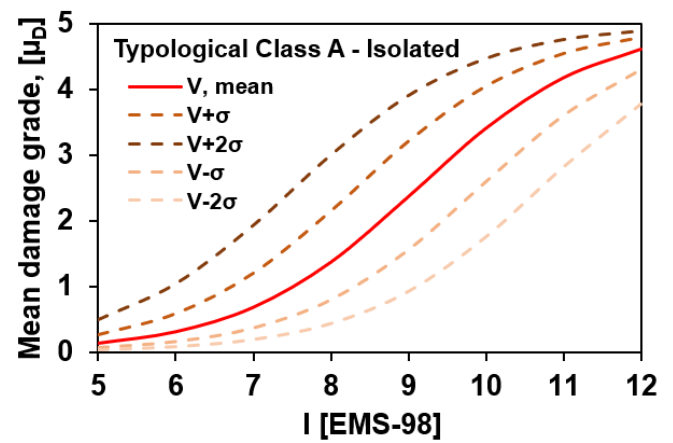

(b)

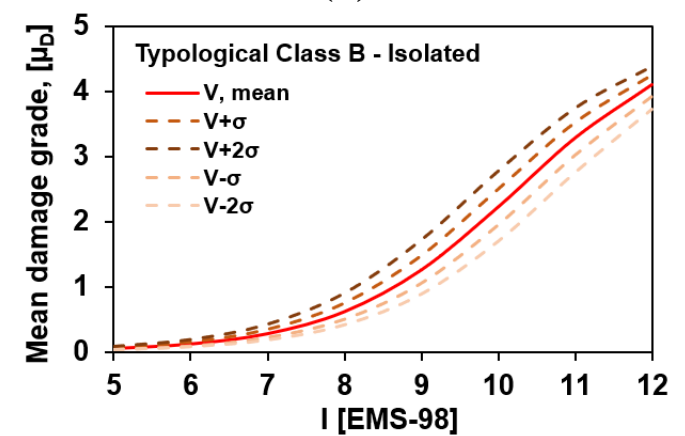

(d)

Fig. (9). Typological vulnerability curves of building classes in aggregated (a, c) and isolated (b, d) conditions detected in Baranello.

\subsection{Damage Scenario}

In the present study, the severity of the seismic damage scenario effects has been analysed by predictive analyses using a proper seismic attenuation law. Generally, the prediction of the seismicity of a specific site can be evaluated by adopting appropriate seismic attenuation laws, which are empirical formulations calibrated on the statistical data (instrumental or macroseismic) analysis of earthquakes occurred. The prerogative of these formulations is to estimate the value of a main synthetic seismic parameter (i.e., accelerations, velocity, seismic intensity, etc.) based on intrinsic factors deriving from the earthquake itself, such as magnitude $\left(\mathrm{M}_{\mathrm{w}}\right)$ and epicentre (R) or hypocentre $(\mathrm{h})$ distances. Several studies $[25,26]$ have been conducted to develop specific attenuation laws for a given area, 
generated in terms of Spectral accelerations $\left(\mathrm{S}_{\mathrm{a}}\right)$ and Peak Ground Accelerations (PGA) or in terms of seismic intensity (MMI), considering a statistical regression of the instrumental data recorded by the earthquakes occurred.

Herein, the propagation of the seismic motion has been described according to the attenuation law proposed by Esteva et al. [27]:

$$
\mathrm{I}_{\mathrm{EMS}-98}=1.45 \times \mathrm{M}_{\mathrm{w}}-2.46 \times \ln (\mathrm{R}+8.16)
$$

Where $\mathrm{M}_{\mathrm{w}}$ is the moment magnitude and $\mathrm{R}$ is the site-tosource distance (measured in $\mathrm{Km}$ ).

Therefore, the analysis conducted is based on an empiricalforecast method, where the probable damage scenarios are estimated by the disaggregation of the seismic risk obtained combining n-sources. In detail, a deterministic approach has been used by selecting as reference earthquakes, according to the Parametric Catalogue of Italian Earthquakes (CPTI15) [28], 3 past events of increasing magnitude (4, 5 and 6), that have influenced the case study municipality. After these moment magnitudes have been selected, the definition of different epicentre distances (in the range from 5 to $35 \mathrm{Km}$ ) has allowed to plot the expected damage scenarios (Fig. 10).

In particular, based on the attenuation law above mentioned, the macroseismic intensities have been correlated to the earthquake magnitudes on the basis of Eq. (5), leading towards the 9 damage scenarios reported in Table 2.

For the sake of representation, the damage scenarios derived from Esteva et al.'s attenuation model considering $\mathrm{R}=5$ $\mathrm{Km}$, which is the most unfavourable case, have been presented in Fig. (11).

Table 2. Correlation between moment magnitude, $M_{w}$, and macroseismic intensity, $I_{\text {EMs-98. }}$

\begin{tabular}{|c|c|c|c|}
\hline \multirow{2}{*}{$\begin{array}{c}\text { Magnitude } \\
\mathrm{M}_{\mathrm{w}}\end{array}$} & $\mathrm{R}=5 \mathrm{Km}$ & $\mathrm{R}=17 \mathrm{Km}$ & \multicolumn{2}{|c|}{ Macroseismic Intensity $\mathbf{I}_{\mathrm{EMS}-98}-$ Esteva et al. (1964) [42] } \\
\cline { 2 - 4 } & $\mathrm{X}$ & $\mathrm{VII}$ & $\mathrm{Km}$ \\
\hline 4 & $\mathrm{XI}$ & $\mathrm{VIII}$ & $\mathrm{VII}$ \\
\hline 5 & $\mathrm{XII}$ & $\mathrm{X}$ & $\mathrm{VIII}$ \\
\hline 6 & & & \\
\hline
\end{tabular}
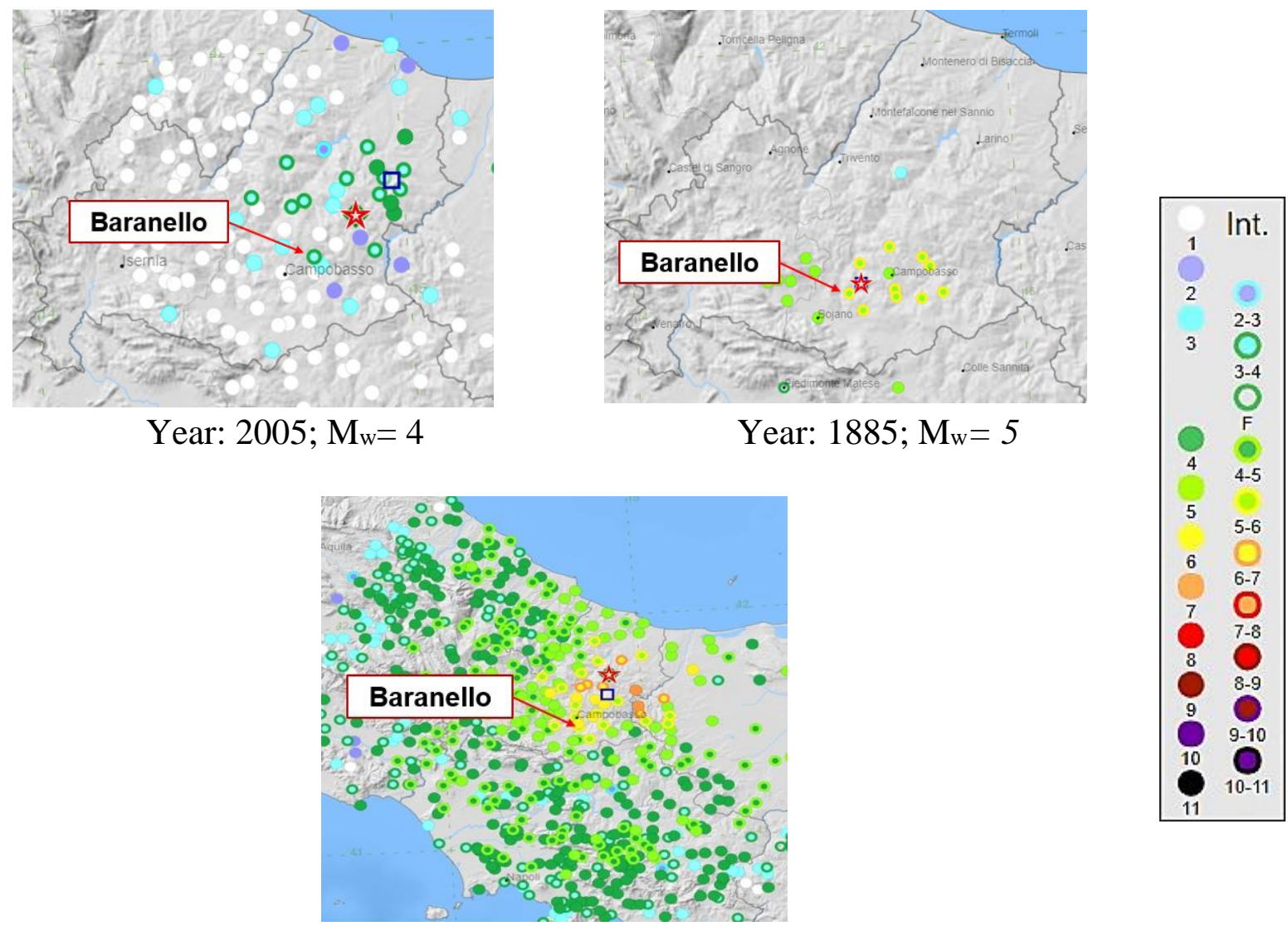

Year: 2002; $\mathrm{M}_{\mathrm{w}}=6$

Fig. (10). The selected seismic events for the case study area. 
For an exhaustive and immediate representation of the damage, the DPM have been developed according to the EMS-98 scale in order to have a specific correlation between the mean damage grade, $\mu_{\mathrm{D}}$, and the probability to achieve a given damage threshold, $D_{K}$ (Fig. 12) $[12,29]$.
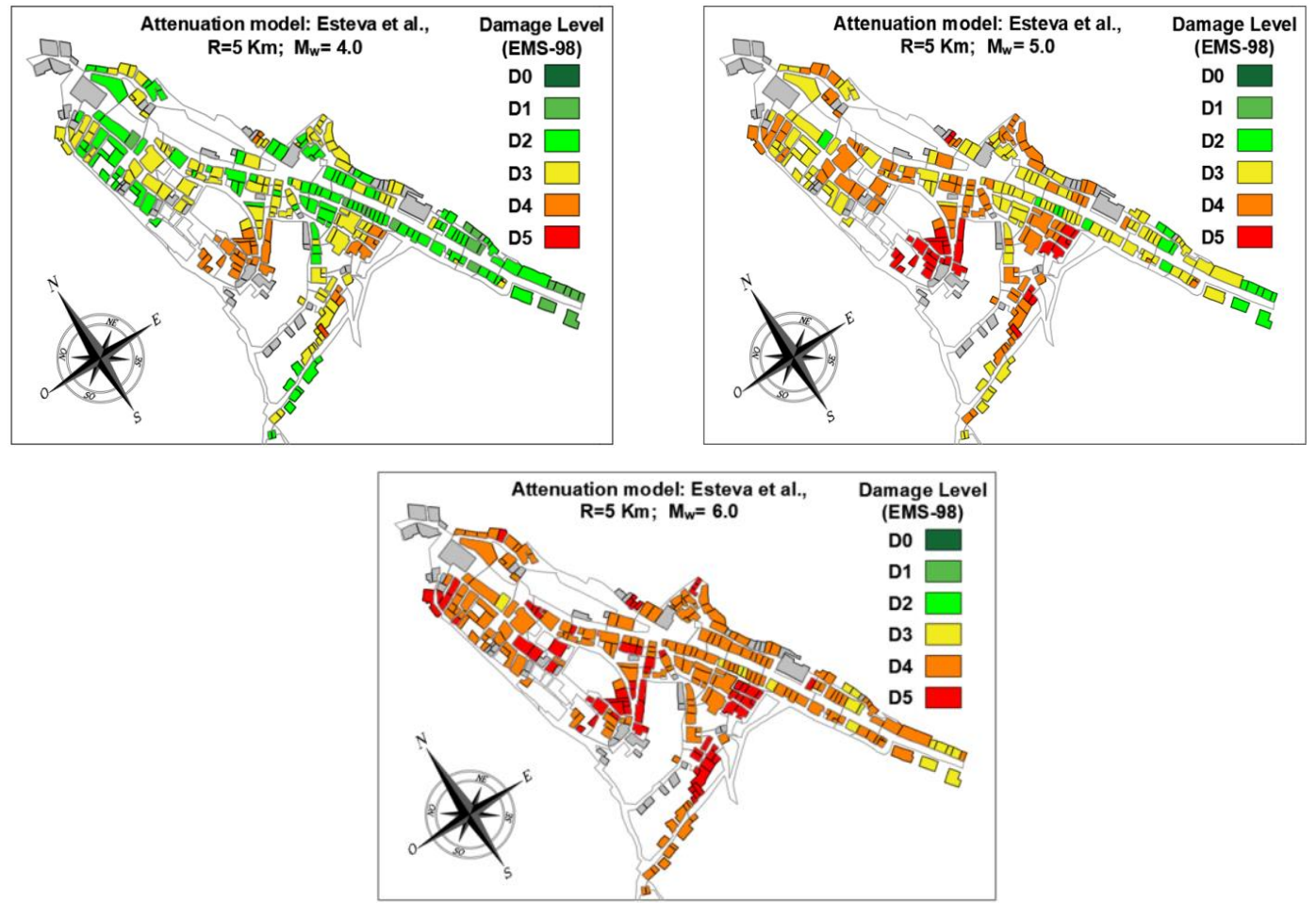

Fig. (11). Damage scenarios detected in the investigated urban area (for $R=5 \mathrm{Km}$ and $\mathrm{M}_{\mathrm{w}}$ variable from 4 to 6 ) according to Esteva et al.'s attenuation law.
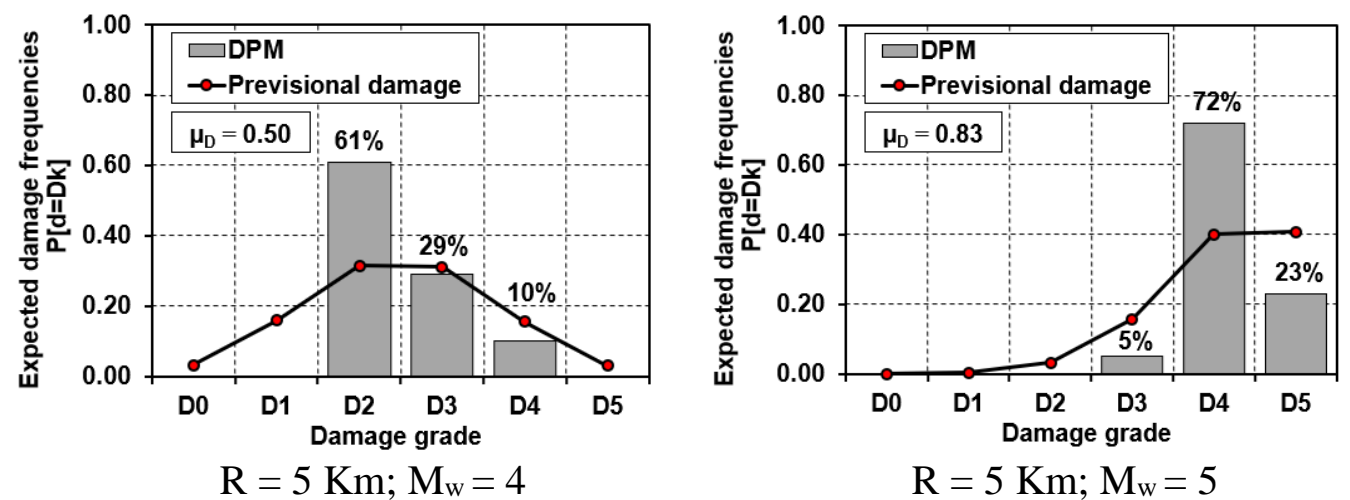

$\mathrm{R}=5 \mathrm{Km} ; \mathrm{M}_{\mathrm{w}}=5$

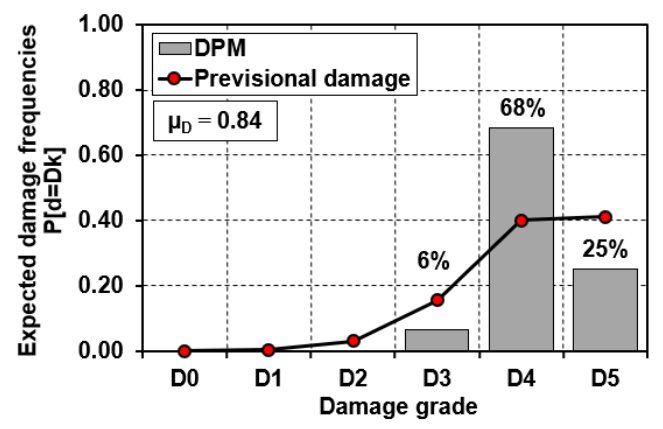

$\mathrm{R}=5 \mathrm{Km} ; \mathrm{M}_{\mathrm{w}}=6$

Fig. (12). Damage Probability Matrices for the selected seismic scenario. 
The results have shown that for $\mathrm{M}_{\mathrm{w}}=4$ about $61 \%$ of the building suffers damage $\mathrm{D} 2$, while for $\mathrm{M}_{\mathrm{w}}=6$, damage thresholds D4 (near-collapse) and D5 (collapse) are attained in $68 \%$ and $25 \%$ of the cases, respectively. Contrary, when $\mathrm{M}_{\mathrm{w}}=$ 5 , a more variable damage distribution is achieved.

\section{DISCUSSION}

\subsection{Vulnerability Analysis Considering Local Site Effects}

\subsubsection{Influence of the Local Hazard Conditions}

In the framework of large-scale vulnerability analysis, the evaluation of local site effects represents one of the most important aspects to be considered for predicting the expected damage in a given area. In fact, when these effects are known, local authorities can implement suitable risk mitigation measures to safeguard people's life and preserve the integrity of historical heritage constructions.

From the physical point of view, the local seismic response can be intended as a set of changes in amplitude, duration and frequency content that a seismic motion, related to a bedrock basement, undergoes through the overlying layers of soil up to the surface. Generally, the main characteristics of the local hazard influence the seismic response of buildings. In particular, two important cases, such as the near-field and farfield earthquakes, could be considered. In the first case (i.e., seismic events characterized by a reduced site-to-source distance, $\mathrm{R}<25 \mathrm{~km}$ ), the ground motion, near the seismogenic source, is associated with the vertically propagating compressive P-waves that, despite having a lower energy content than the horizontal ones (S-waves), tend to concentrate all the energy input in a restricted area, producing, in case of unfavourable site conditions, very devastating effects on the engineering structures. In the second case (far-field phenomena), the seismic waves effects tend to attenuate with the distance $(\mathrm{R}>100 \mathrm{~km})$ between the site and the seismic source [30 - 32].

As it is known, a generic ground motion can be described in either time or frequency domains. In the first case, the parameters most frequently used are the peak value of the acceleration, the velocity, the displacement and the duration. In the second case, the parameters of seismic motion are characterized by either Fourier spectrum or response spectrum. In the specific case study, the quantitative evaluation of the local seismic response, $\mathrm{f}_{\mathrm{PGA}}$, has been carried out based on the ratio between the maximum acceleration at the ground surface, considering the soil specific properties $\left(\mathrm{a}_{\max , \mathrm{s}}\right)$ and that at the bedrock $\left(\mathrm{a}_{\max , \mathrm{r}}\right)$, as reported in the following equation:

$$
f_{\mathrm{PGA}}=\frac{a_{\mathrm{max}, \mathrm{s}}}{a_{\mathrm{max}, \mathrm{r}}}
$$

\subsubsection{D-Simplified Approach for the Evaluation of Site Effects}

The local amplification factor illustrated in Eq. (6) has been evaluated according to time domain based on the unscaled natural accelerogram of the event occurred in Molise in 2002 (epicentre located in Bonefro). The event was characterized by a magnitude, $\mathrm{M}_{\mathrm{w}}$, equal to 6.0 with a maximum $\mathrm{PGA}=0.55 \mathrm{~g}$. To simulate exhaustively local effects, STRATA 1.0 software [33], developed at the University of Texas, has been used considering a 1D numerical simulation of geological conditions of seismic motion at bedrock. Operatively, note the accelerogram at ground surfaces, it is possible to "relocate" the seismic input at the bedrock. In particular, once the soil stratigraphy is defined, the software implicitly takes into account the physical-mechanical characteristics of the soil layers.

So, based on this consideration, the soil profile has been assumed according to the study proposed in [12], characterized by a particular geological structure mainly derived from covering tectonics related to the formation of the Apennine chain and sub-Apennine reliefs with a bedrock basement located at $30 \mathrm{~m}$ of depth. In Fig. (13), the elaborated seismic motions with (amplified) and without (bedrock) local site effects have been plotted.

From the previous figure, the local site amplification factor, $\mathrm{f}_{\mathrm{PGA}}$, has been estimated as the maximum ratio between the detected accelerations (amplified and at bedrock) according to the aforementioned Eq. 6. As shown in Table 3, such a factor is equal to 1.33 , which means that the seismic accelerations at the ground surface are $33 \%$ greater than those at the bedrock.

\subsubsection{Influence of Site Effects on Vulnerability and Fragility Curves}

Once the local amplification factor has been defined, it is possible to take into account the influence of the site effects in terms of typological vulnerability and fragility curves. Operationally, a more suitable vulnerability index of the inspected buildings, $\mathrm{V}_{\mathrm{I}, \mathrm{s}}$, is calculated as the product between the contribution of the local amplification factor and the normalized vulnerability index:

$$
\mathrm{V}_{\mathrm{I}, \mathrm{s}}=\mathrm{f}_{\mathrm{PGA}} \times \mathrm{V}_{\mathrm{I}}
$$

Therefore, it is possible to consider in a simplified manner the influence of the effects on the vulnerability assessment of the examined area. As shown in Table 3, the increase of vulnerability is directly proportional to the local amplification factor, estimated equal to $33 \%$. Thus, the average typological vulnerability index, evaluated considering the site effects (Eq. 7), becomes equal to 0.73 and 0.48 for building classes $\mathrm{A}$ and $\mathrm{B}$, respectively. Consequently, it seems quite evident that the increase of normalized vulnerability index has generated an almost proportional increase of the expected damage in terms of both vulnerability and fragility curves. Thus, the mean typological vulnerability curves, obtained by means of Eq. 4 (Section 3.1), have also been derived taking into account site effects, as shown in Fig. (14).

Furthermore, a synthetic representation of the new achieved damages has been done by means of DPMs shown in Fig. (15), where the previous combinations of magnitudes and site-source distances have been taken into consideration [12]. 
Table 3. Local amplification factor, $\mathbf{f}_{\mathrm{PGA}}$, for the Molise seismic event.

\begin{tabular}{|c|c|c|c|}
\hline \multirow{2}{*}{$\begin{array}{c}\text { Time } \\
\text { History }\end{array}$} & Amplified $-\mathrm{a}_{\max , \mathrm{s}}$ & Bedrock $-\mathrm{a}_{\max , \mathrm{r}}$ & $f_{P G A}$ \\
\cline { 2 - 4 } & 0.56 & 0.42 & 1.33 \\
\hline $10 \mathrm{~s}$ & Acceleration $[\mathbf{g}]$ & \\
\hline
\end{tabular}

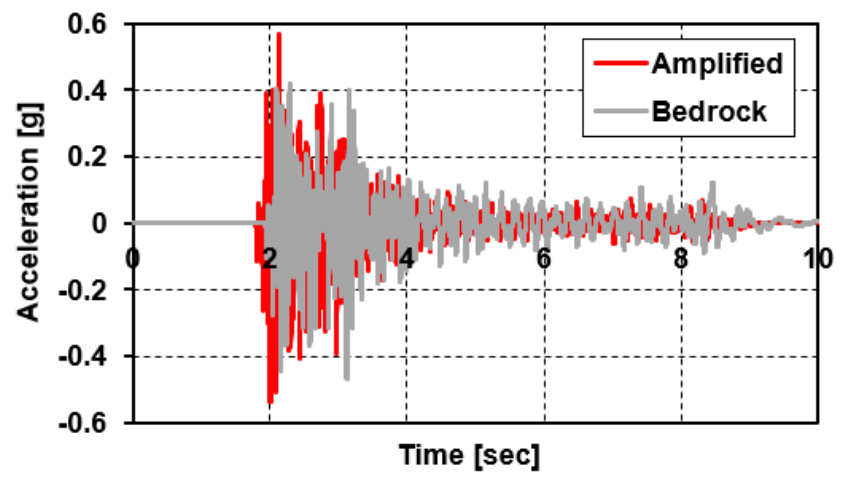

Fig. (13). The simulated accelerograms.

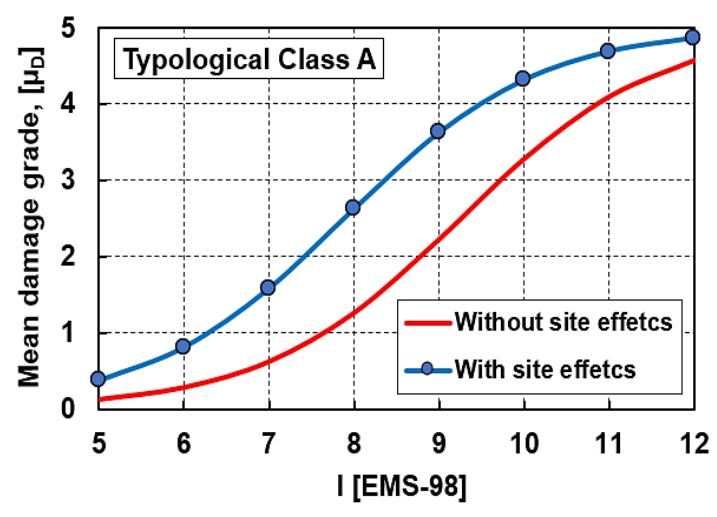

(a)

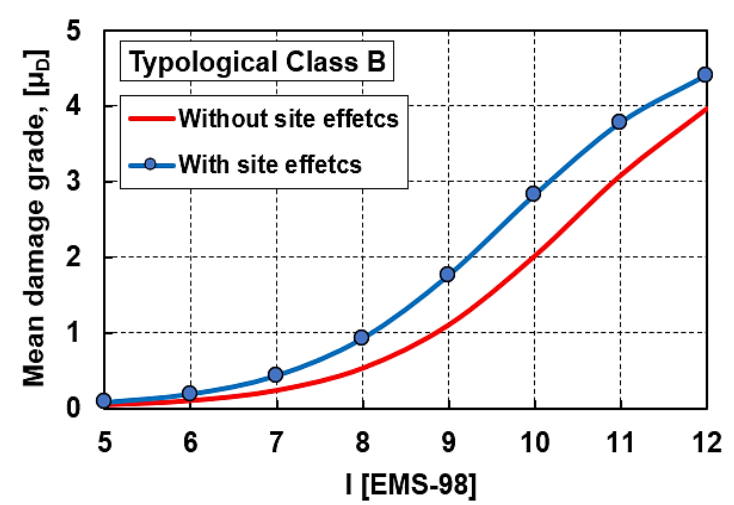

(b)

Fig. (14). Typological mean vulnerability curves considering local site effects for (a) class A and (b) class B buildings.

Thus, by comparing the new damage scenarios Fig. (15) with those reported in Section 3.2 (Fig. 12), it has been possible to evaluate the damage increase due to local site effects (Fig. 16).

The results have shown that, for an epicentre distance of 5 $\mathrm{km}$, the damage distribution tends to increase towards higher damage levels as the magnitude increases. This result is markedly evident when considering $\mathrm{M}_{\mathrm{w}}=6$, since the damage level D4 is drastically reduced, while the D5 one is strongly increased.

Subsequently, the typological fragility curves related to the building classes examined considering the influence of soil conditions have been suitably elaborated and compared to those where geological effects have been neglected.
Therefore, as proposed in [34], the fragility curves have been derived considering the correlation law between macroseismic intensity and seismic acceleration:

$$
\log \left(\mathrm{a}_{\mathrm{g}}\right)=\mathrm{C}_{1} \times \mathrm{I}_{\text {EMS-98 }}-\mathrm{C}_{2} \quad[\mathrm{~g}]
$$

where the coefficients $\mathrm{C}_{1}$ and $\mathrm{C}_{2}$ have been assumed equal to 0.602 and 7.073 , respectively. The comparison among fragility curves achieved with and without site effects is presented in Fig. (17).

The results show a clear preponderance of damage when site effects are considered for both typological classes examined. In particular, it has been observed that considering site effects, the damage probability tends to increase much more for ultimate limit states (from D3 to D5) than for serviceability limit states (D1 and D2). 


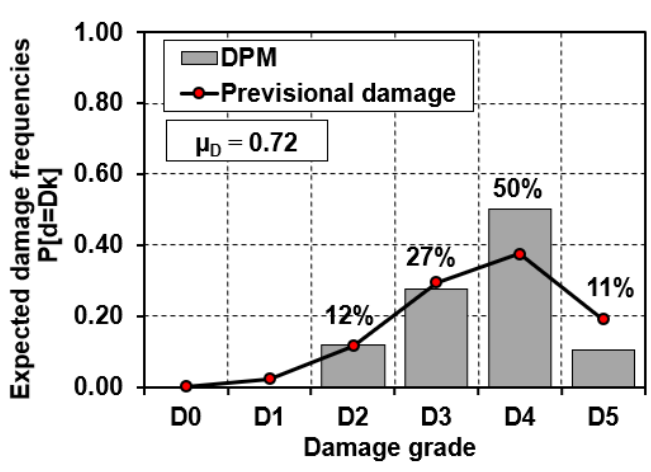

$\mathrm{R}=5 \mathrm{Km} ; \mathrm{M}_{\mathrm{w}}=4$

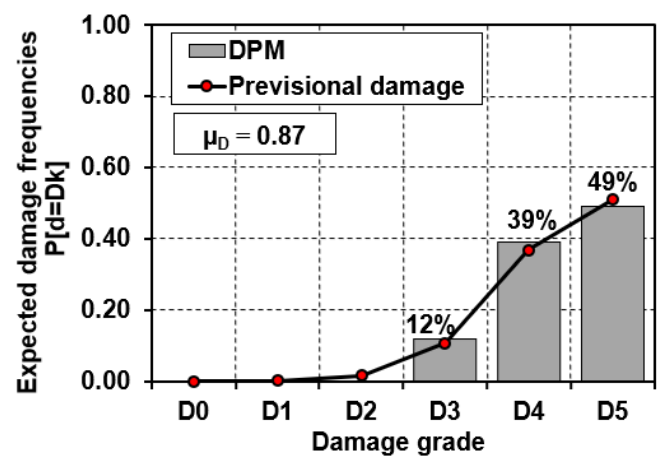

$\mathrm{R}=5 \mathrm{Km} ; \mathrm{M}_{\mathrm{w}}=5$

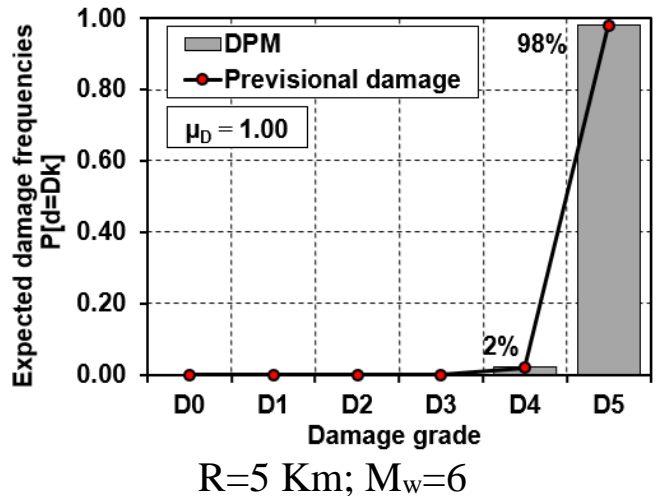

Fig. (15). DPMs considering local seismic amplification effects.

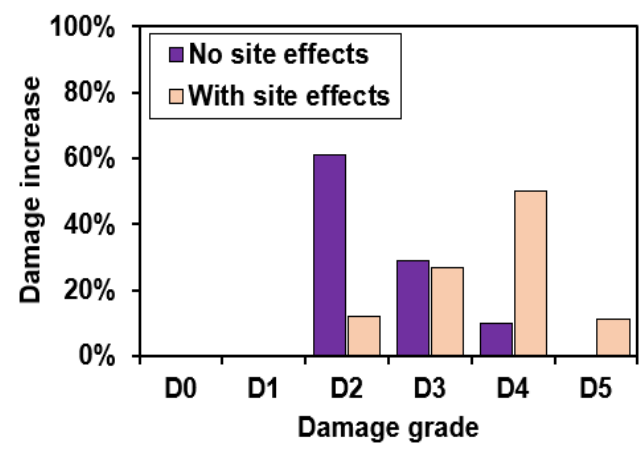

(a) - $\mathrm{R}=5 \mathrm{Km} ; \mathrm{M}_{\mathrm{w}}=4$

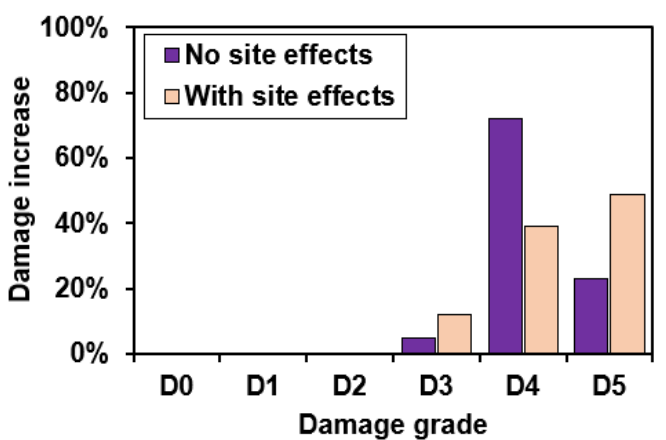

(b) $-\mathrm{R}=5 \mathrm{Km} ; \mathrm{M}_{\mathrm{w}}=5$

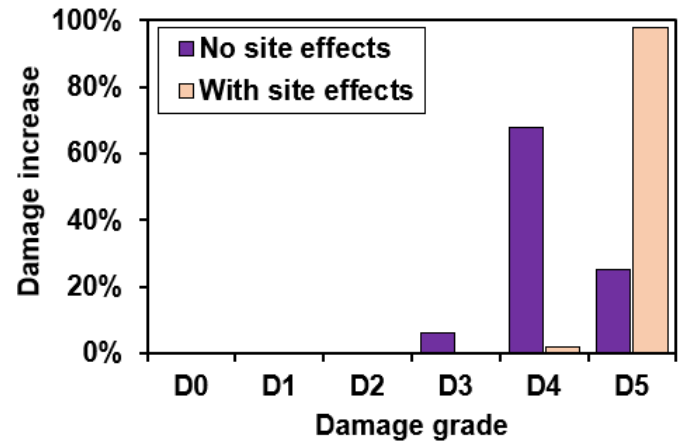

(c) - $\mathrm{R}=5 \mathrm{Km} ; \mathrm{M}_{\mathrm{w}}=6$

Fig. (16). Comparison among damage scenarios with and without site effects. 


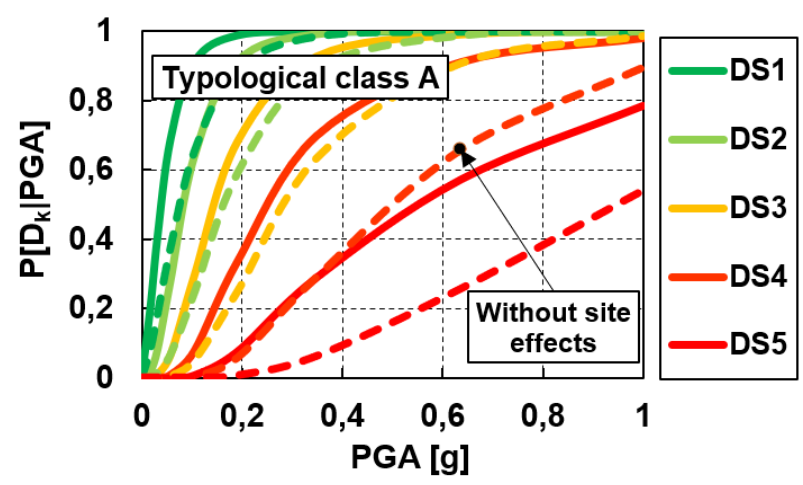

(a)

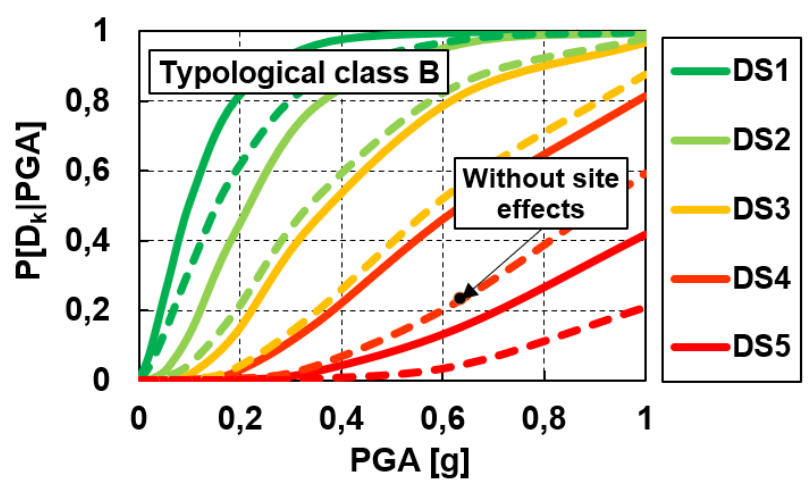

(b)

Fig. (17). Fragility assessment of the building classes with and without site effects for the typological classes analysed.

\section{CONCLUSION}

The study herein presented and discussed has proposed a novel and refined methodology to analyse the seismic vulnerability of masonry building aggregates in historic centres considering the influence of geo-hazard conditions. To this purpose, an urban sector with 300 buildings of the historical centre of Baranello in the Molise Region of Italy has been identified as a reference study area. The surveyed buildings have been firstly classified typologically and structurally according to the CARTIS form and then sub-divided subdivided in two different typological classes (A and B) based on the classification proposed by the European Macroseisic Scale EMS-98.

As a first step of the study, the seismic vulnerability assessment has been conducted by means of an empirical approach appropriately conceived for structural units of masonry building compounds.

Subsequently, for the quantification of the observed damage, the AeDES form, conjunctly with the Da.D.O database, have been adopted to statistically derive the Damage Probability Matrices.

Finally, the damage scenarios for different moment magnitudes and site-source distances based on the historical seismicity of the area have been derived by means of an appropriate seismic attenuation law. From the performed analyses, the following outcomes have been achieved:

- The vulnerability distribution for buildings of the typological class A is quite homogeneous, with an expected medium-high vulnerability level enclosed in the range [0.4-0.6]. Contrary, for buildings of the typological class $\mathrm{B}$, the expected vulnerability index is in the range [0.2-0.4], which corresponds to a moderate vulnerability level.

- The results achieved from Damage Probability Matrices have shown that $38 \%$ of the buildings have damage D0 (null), while $36 \%$ of them reached a damage level D1 (negligible to slight damage).

- The damage scenarios of the investigated urban sector based on the Esteva et al.'s seismic attenuation have provided, in case of moment magnitude, $\mathrm{M}_{\mathrm{w}}$, equal to 6.0, a damage threshold $\mathrm{D} 4$ (near-collapse) in $68 \%$ of buildings and a damage threshold D5 (collapse) in $25 \%$ of cases.

In the second study step, the site effects have been evaluated according to the simplified procedure based on the 1D half-space geological condition approach. To this purpose, the unscaled natural accelerogram of the event occurred in Molise in 2002 (epicentre located in Bonefro) with $\mathrm{M}_{\mathrm{w}}$ of 6.0 and maximum $\mathrm{PGA}=0.55 \mathrm{~g}$ has been considered. Local site effects have been taken into account through a local amplification factor given by the ratio between the maximum acceleration deriving from the specific soil type and that at the bedrock. From analyses carried out, the following results have been obtained:

- The stratigraphy of the site has produced an acceleration percentage increment of $33 \%$ compared to the bedrock acceleration;

- The global vulnerability of inspected buildings has been therefore increased due to local site effects. In parti-cular, the average vulnerability index of typological classes of buildings $\mathrm{A}$ and $\mathrm{B}$ has become 0.73 and 0.48 , respectively;

- The mean typological vulnerability curves have been modified considering geo-hazard conditions. In the worst analysis scenario, obtained for $\mathrm{R}=5 \mathrm{~km}$ and $M_{w}=6$, the site effects have drastically reduced the damage levels D3 and D4 and have increased significantly the threshold D5, with the collapse of $98 \%$ of buildings in the analysed area;

- The typological fragility functions of buildings have been derived considering local site effects. The results have shown a clear damage increase with site effects for both typological classes examined. In particular, it has been noticed that the damage probability tends to increase much more for ultimate limit states than for serviceability limit ones.

In conclusion, the proposed work has provided a simplified effective approach for evaluating site effects in large-scale 
analysis of masonry building compounds. Such an analysis method could represent an important tool for predicting damage scenarios in historic centres in a more precise way. Further developments of the study can foresee the application of the methodology to other seismic regions characterized by different types of masonry buildings and geological conditions to plan more effective seismic risk mitigation interventions.

\section{CONSENT FOR PUBLICATION}

Not applicable.

\section{AVAILABILITY OF DATA AND MATERIALS}

The data that support the findings of this study are available from the corresponding author, [A.F], upon reasonable request.

\section{FUNDING}

None.

\section{CONFLICT OF INTEREST}

The authors declare no conflict of interest, financial or otherwise

\section{ACKNOWLEDGEMENTS}

The current research activity was developed within the WP2 CARTIS of the DPC-ReLUIS 2019-2021 Italian research project, which is gratefully acknowledged by the Authors.

\section{REFERENCES}

[1] T.M. Ferreira, R. Maio, and R. Vicente, "Seismic vulnerability assessment of the old city centre of Horta, Azores: Calibration and application of a seismic vulnerability index method", Bull. Earthquake Eng., vol. 15, pp. 2879-2899, 2017.

[http://dx.doi.org/10.1007/s10518-016-0071-9]

[2] N. Chieffo, A. Formisano, and T.M. Ferreira, "Damage scenario-based approach and retrofitting strategies for seismic risk mitigation: An application to the historical Centre of Sant'Antimo (Italy)", Eur. J. Environ. Civ. Eng., 2019.

[http://dx.doi.org/10.1080/19648189.2019.1596164]

[3] P.B. Lourenço, D.V. Oliveira, J.C. Leite, J.M. Ingham, C. Modena, and F. da Porto, "Simplified indexes for the seismic assessment of masonry buildings: international database and validation", Eng. Fail. Anal., vol. 34, pp. 585-605, 2014.

[http://dx.doi.org/10.1016/j.engfailanal.2013.02.014]

[4] A.H. Barbat, M.L. Carreño, L.G. Pujades, N. Lantada, O.D. Cardona, and M.C. Marulanda, "Seismic vulnerability and risk evaluation methods for urban areas. A review with application to a pilot area", Struct. Infrastruct. Eng., vol. 6, pp. 17-38, 2010. [http://dx.doi.org/10.1080/15732470802663763]

[5] M. Dolce, A. Kappos, A. Masi, G. Penelis, and M. Vona, "Vulnerability assessment and earthquake damage scenarios of the building stock of Potenza (Southern Italy) using Italian and Greek methodologies", Eng. Struct., vol. 28, pp. 357-371, 2006. [http://dx.doi.org/10.1016/j.engstruct.2005.08.009]

[6] F. Clementi, V. Gazzani, M. Poiani, and S. Lenci, "Assessment of seismic behaviour of heritage masonry buildings using numerical modelling", J. Build. Eng., vol. 8, pp. 29-47, 2016. [http://dx.doi.org/10.1016/j.jobe.2016.09.005]

[7] F. Cacace, G. Zuccaro, D. De Gregorio, and F.L. Perelli, "Building Inventory at National scale by evaluation of seismic vulnerability classes distribution based on Census data analysis: BINC procedure", Int. J. Disaster Risk Reduct., vol. 28, pp. 384-393, 2018. [http://dx.doi.org/10.1016/j.ijdrr.2018.03.016]

[8] M. Mosoarca, I. Onescu, and E. Onescu, "A, Anastiasadis, "Seismic vulnerability assessment methodology for historic masonry buildings in the near-field areas", Eng. Fail. Anal., vol. 115, 2020. [http://dx.doi.org/10.1016/j.engfailanal.2020.104662]

[9] I. Apostol, M. Mosoarca, and N. Chieffo, Structural Analysis of Historical Constructions, Springer, Cham, 2019.https://link.springer.com/chapter/10.1007/978-3-319-99441-3_12 8 \#citeas

[10] A. Formisano, "Theoretical and Numerical Seismic Analysis of Masonry Building Aggregates: Case Studies in San Pio Delle Camere (L'Aquila, Italy)", J. Earthquake Eng., vol. 21, pp. 227-245, 2017. [http://dx.doi.org/10.1080/13632469.2016.1172376]

[11] M. Mosoarca, I. Onescu, E. Onescu, B. Azap, N. Chieffo, and M. Szitar-Sirbu, "Seismic vulnerability assessment for the historical areas of the Timisoara city, Romania", Eng. Fail. Anal., vol. 101, pp. 86-112, 2019.

[http://dx.doi.org/10.1016/j.engfailanal.2019.03.013]

[12] N. Chieffo, and A. Formisano, "Induced Seismic-Site Effects on the Vulnerability Assessment of a Historical Centre in the Molise Region of Italy: Analysis Method and Real Behaviour Calibration Based on 2002 Earthquake", Geosciences (Basel), vol. 10, no. 21, 2020. [http://dx.doi.org/10.3390/geosciences10010021]

[13] S. Lagomarsino, and S. Giovinazzi, "Macroseismic and mechanical models for the vulnerability and damage assessment of current buildings", Bull. Earthquake Eng., vol. 4, pp. 415-443, 2006. [http://dx.doi.org/10.1007/s10518-006-9024-z]

[14] S. Giovinazzi, "Geotechnical hazard representation for seismic risk analysis", Bulletin of the New Zealand Society for Earthquake Engineering, vol. 42, 2009.

[http://dx.doi.org/10.5459/bnzsee.42.3.221-234]

[15] G. Lanzo, F. Silvestri, A. Costanzo, A. d'Onofrio, L. Martelli, A. Pagliaroli, S. Sica, and A. Simonelli, "Site response studies and seismic microzoning in the Middle Aterno valley (L'aquila, Central Italy)", Bull. Earthquake Eng., vol. 9, pp. 1417-1442, 2011.

[http://dx.doi.org/10.1007/s10518-011-9278-y]

[16] S. Suwal, A. Pagliaroli, and G. Lanzo, "Comparative study of 1D codes for site response analyses", Int. J. Landslide. Environ., vol. 2, pp. 24-31, 2014.

[17] N. Chieffo, and A. Formisano, "The influence of geo-hazard effects on the physical vulnerability assessment of the built heritage: An application in a district of Naples", Buildings, vol. 9, 2019. [http://dx.doi.org/10.3390/buildings9010026]

[18] Viaggio Molise, $n . d$. .https://www.viaggiomolise.it/baranello/

[19] G. Zuccaro, M. Della Bella, and F. Papa, "Caratterizzazione tipologico strutturali a scala nazionale", Proceedings of the 9th National Conference ANIDIS, 1999 L'Ingegneria Sismica in Italia, Italy

[20] C. Baggio, A. Bernardini, R. Colozza, L. Corazza, M. Della Bella, G. Di Pasquale, M. Dolce, A. Goretti, A. Martinelli, G. Orsini, F. Papa, and G. Zuccaro, Manuale per la compilazione della scheda di primo livello di rilevamento danno, pronto intervento e agibilità per edifici ordinari nell'emergenza post-sismica (AeDES), 2009.http://www.protezionecivile.gov.it/media-comunicazione/pubblic azioni/dettaglio/-/asset_publisher/default/content/manuale-per-lacompilazione-della-scheda-di-1-livello-di-rilevamento-di-dannopronto-intervento-e-agibilita-per-edifici-ordinari-nell-emergenza-posts

[21] European Centre for Training and Research in Earthquake Engineering, Database di Danno Osservato (Da.D.O), (n.d.)..http://egeos.eucentre.it/danno_osservato/web/danno_osservato\#

[22] D. Rapone, G. Brando, E. Spacone, and G. De Matteis, "Seismic vulnerability assessment of historic centers: Description of a predictive method and application to the case study of scanno (Abruzzi, Italy)", Int. J. Archit. Herit., vol. 12, pp. 1171-1195, 2018.

[http://dx.doi.org/10.1080/15583058.2018.1503373]

[23] A. Formisano, G. Florio, R. Landolfo, and F.M. Mazzolani, "Numerical calibration of an easy method for seismic behaviour assessment on large scale of masonry building aggregates", Adv. Eng. Softw., vol. 80, pp. 116-138, 2015.

[http://dx.doi.org/10.1016/j.advengsoft.2014.09.013]

[24] D. Benedetti, and V. Petrini, "On the seismic vulnerability of masonry buildings: An evaluation method", L'Industria Delle Costr., vol. 149, pp. 66-74, 1984. [in Italian].

[25] G.R. Toro, N.A. Abrahamson, and J.F. Schneider, "Model of Strong Ground Motions from Earthquakes in Central and Eastern North America: Best Estimates and Uncertainties", Seismol. Res. Lett., vol. 68, pp. 41-57, 1997. [http://dx.doi.org/10.1785/gssrl.68.1.41]

[26] G.M. Atkinson, and S.L.I. Kaka, "Relationships between felt intensity and instrumental ground motion in the Central United States and California", Bull. Seismol. Soc. Am., vol. 97, pp. 497-510, 2007. 
[http://dx.doi.org/10.1785/0120060154]

[27] D. Esteva, and D.L. Harris, "Comparison of pressure and staff wave gage records", Coastal Engineering Proceedings, vol. 1, p. 7, 1970. [http://dx.doi.org/10.9753/icce.v12.7]

[28] M. Locati, DBMI15, the 2015 Version of the Italian Macroseismic Database, 2016.https://emidius.mi.ingv.it

[29] G. Grünthal, European Macroseismic Scale 1998.http://lib. riskreductionafrica.org/bitstream/handle/123456789/1193/1281.Europ ean $\% 20$ Macroseismic\% $\% 20$ Scale $\% 201998$.pdf?sequence $=1$

[30] N. Chieffo, I. Onescu, A. Formisano, M. Mosoarca, and M. Palade, "Integrated empirical-mechanical seismic vulnerability analysis method for masonry buildings in timișoara: Validation based on the 2009 Italian Earthquake", Open Civ. Eng. J., vol. 14, pp. 314-333, 2020 . [http://dx.doi.org/10.2174/1874149502014010314]

31] V. Gioncu, F.M. Mazzolani, Eds., Spon Press. London, 2011.

[32] F. Di Michele, C. Cantagallo, and E. Spacone, "Effects of the vertical seismic component on seismic performance of an unreinforced masonry structures", Bull. Earthquake Eng., vol. 18, pp. 1635-1656, 2020 .

[http://dx.doi.org/10.1007/s10518-019-00765-3]

[33] P.B. Flemings, J.P. Grotzinger, and J.E. Morris, Strata: $A$ Stratigraphic Modeling Package.http://www.jsg.utexas.edu/flemings/ intranet/software/strata/strata-download-the-code-manual-and-tutorial/ n.d.

[34] E. Guagenti, and V. Petrini, "The Case of Old Buildings: Towards a New Law Intensity Damage", In Proceedings of the 12th Italian Conference on Earthquake Engineering, ANIDIS, 1989 Italian National Association of Earthquake Engineering, Pisa, Italy

\section{(C)2021 Formisano. et al.}

This is an open access article distributed under the terms of the Creative Commons Attribution 4.0 International Public License (CC-BY 4.0), a copy of which is available at: https://creativecommons.org/licenses/by/4.0/legalcode. This license permits unrestricted use, distribution, and reproduction in any medium, provided the original author and source are credited. 